\title{
URGENSITAS TARJîH DALAM ISTINBÂTH HUKUM ISLAM
}

\author{
Ainol Yaqin \\ (Jurusan Syariah STAIN Pamekasan, Jl. Raya Panglegur Km. 4 Pamekasan, \\ email: ainulfairus@ymail.com)
}

\begin{abstract}
Abstrak
Tarjîh merupakan salah satu perangkat metode istinbâth hukum Islam. Metode ini diformulasikan oleh ulama ushul fiqh guna menemukan titik terang dalam menetapkan hukum Islam di antara dalil-dalil yang berta'ârudl. Eksistensi metode ini sangat penting dalam rangka memilah dan memilih dalil al-Qur'an dan Hadits yang râjih di antara beberapa dalil lain yang berkaitan dengan suatu persoalaan hukum. Oleh karena itu, kalangan ulama' ushul al-[-Hanafiyyah, al-Mâlikiyyah, al-Syâfi'iyyah, alHanâbilah dan al-Zhâhiriyyah merumuskan langkah-langkah yang mesti ditempuh untuk memecahkan kebuntuan dalam dalil-dalil yang ber-ta'ârudl. Kalangan al- $\underline{H}$ anafìyyah menempuh empat cara untuk mencairkan dua atau beberapa dalil al-Qur'an dan Hadits yang bertentangan, yaitu pertama, al-naskh (menghapus, membatalkan), kedua, al-tarjîh (menguatkan, mengunggulkan), ketiga, al-jam' wa al-tawfiq (menggabung dan mengkompromikan) dan terakhir tasâquth al-dalîlaiyn (menggugurkan dan beralih pada dalil lain). Sedangkan, metode-metode penyelesaian dalil-dalil bertentangan yang digunakan kalangan al-Mâlikiyyah, al-Syâfí'iyyah, al-Hanâbilah dan al-Zhâhiriyyah adalah pertama, al-jam' wa al-tawfiq bayn almuta'âridlayn bi wajh maqbûl (mengumpulkan dan mengkom promikan dalil-dalil yang bertentangan sekalipun dari satu sisi), kedua, al-tarjîh, ketiga, al-naskh dan tasâquth al-dalîlayn. Tarjîh dapat dilakukan dengan mempertimbangkan beberapa segi, yaitu a. Sanad (mata rantai perawi Hadits), b. Matan (teks Hadits), c. Hukum yang dikandung nash (ayat atau Hadits) dan d. Pentarjîhan dari dalil lain.
\end{abstract}

Abstract
Tarjîh is a method tool of istinbâth in Islamic law. The method is
formulated by ulama' ushul to find a bright spot to set Islamic
law among the opposite theorems. The existence of the method

al-1hkâm Vol.10 No.1 Juni 2015 
is very important in choosing strong/pure al-Qur'an texts and Hadits from some of the other Hadits related to the law problems. Therefore, the ulama' ushul fiqh al-Hanafiyyah, alMâlikiyyah, al-Syâfi'iyyah, al-Hanâbilah dan al-Zhâhiriyyah construct steps to take to solve the dead end in ijtihad when they face some contradictory theorems. Al-Hanafiyyah takes four ways to deal with two or more contradictory al-Qur'an texts and Hadits. First, al-naskh (to clear, to cancel), second, altarjîh (to strengthen, to favor), third, al-jam' wa al-tawfiq (to combine, to compromise) and the last is tasâquth al-dalilayn (to break and move to another theorems). While, methods used to deal with the contradictory theorems by al-Mâlikiyyah, al-

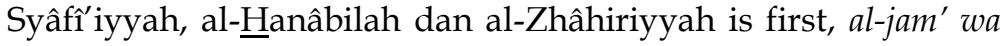
al-tawfiq bayn al muta'aridlayn bi wajh maqbul (collect and compromise the contradictory theorems from one side), second, al-tarjîh, the third, al-naskh and the last is tasâquth al-dalilayn. Tarjîh can be done by considering some sides, those are, a. Sanad side (The chain of Hadits reader), b. Matan side (Hadits text), c. Law contained in the law side (text or Hadits) and d. translation from other theorems.

\author{
Kata Kunci: \\ al-Qur'an, Hadits, ta'ârudl al-adillah, tarjîh, hukum Islam
}

\title{
Pendahuluan
}

Al-Qur'an yang terdiri dari 6236 ayat secara substansi antara ayat satu dengan yang lainnya saling berkesesuaian, tidak mungkin terdapat pertentangan, baik dari segi makna ataupun hukumnya. Begi tu juga Hadits yang shahîh tidak mungkin bertolakbelakang dengan ketentuan al-Qur'an dan Hadits-Hadits lainnya yang sederajat. Akan tetapi, secara lahiriyah terdapat "pertentangan" dalil-dalil (ta'ârudl aladillah) antara al-Qur'an dengan al-Qur'an, al-Qur'an dengan Hadits, atau pun Hadits dengan Hadits itu dapat terjadi bilamana secara teknis satu "tingkatan".

Sekalipun secara subtansial antara dalil-dalil itu tidak mung kin ada pertentangan, tetapi apabila dianggap ada pertentangan hal itu hanya berdasarkan penilaian diri subjektif mujtahid. Oleh karena itu, ulama ushul merumuskan metode-metode tarjîh agar dapat "menengahi" pertentangan dalil-dalil tersebut. 
Apabila ada suatu dalil menunjukkan hukum pada suatu kasus dan ditemukan pula dalil lain yang menuntut diberlakukannya hukum pada kasus itu, maka kedua dalil itu disebut dalam terma ushul fiqh dengan ta'ârudl, ta'âdul, atau taqâbul. Dalam masalah ini, seorang mujtahid dituntut untuk mencurahkan segenap pikirannya guna mencairkan "pertentangan" antar dalil-dalil supaya diketemu kan mana dalil yang lebih kuat (râjih) dan dapat dijadikan pijakan (hujjah).

\section{Pengertian $\mathrm{Ta}^{\prime}$ ârudl al-Adillah}

Ulama ushul fiqh mengemukakan definisi ta'ârudl al-adillah dengan pelbagai ungkapan. Al-Syawkanî dan al-Khudharî Bek men definisikannya dengan: "Salah satu dalil menghendaki suatu hukum pada suatu kasus dan terdapat dalil lain yang menghendaki hukum berbeda pada kasus itu". ${ }^{1}$ Ulama ushul yang lain seperti Muhammad al-Ansharî dan al-Kamâl bin al-Hammâm memberi pengertian $t a^{\prime}$ ârudl al-dillah adalah "pertentangan dua dalil atau bebe rapa dalil yang menghendaki putusan hukum berbeda, yang tidak mungkin dikom promikan antara keduanya". ${ }^{2}$

Apabila ada sebuah dalil menghendaki ketetapan hukum wajib, sedangkan dalil yang lain menghendaki hukum haram, maka pertentangan antar dalil-dalil dapat terjadi jika kualitasnya sederajat. Misalnya, ayat al-Qur'an dengan ayat al-Qur'an yang lain, Hadits mutawâtir dengan Hadits mutawâtir yang lain, Hadits ahad dengan Hadits ahad yang lain atau qiyâs dengan qiyâs yang lain. Sebaliknya, tidak akan terjadi pertentangan antar dalil yang tidak sederajat, misalnya, ayat al-Qurân berbenturan dengan Hadits ahad atau Hadits mutawâtir bertentangan dengan Hadits ahad dan seterusnya. Apabila terjadi pertentangan kandungan hukum antara dalil yang kualitasnya

1 Muhammad al-Syawkanî, Irsyâd al-Fuhûl, (Beirut: Dâr al-Fikr, 1998), hlm. 241, Muhammad al-Khudharî Bek, Ushûl al-Fiqh (Beirut: Dâr al-Fikr, 1988), hlm. 358.

2 Muhammad bin Nidhâmuddîn al-Ansharî, Fawâtif al-Rahamût, Jld. II (Beirut: Dâr alFikr, t.th), hlm. 189, al-Kamâl bin al-Hammâm, al-Taqrîr wa al-Tahbîr fî 'Ilm al-Ushûl alJâmi' bayn Isthilâhay al-Hanafiyah wa al-Syâfi'iyyah, Jld. III (Beirut: Dâr al-Kutub al'Ilmiah, 1983) hlm. 2, Wahbah al-Zuhaylî, Ushûl al-Fiqh al-Islâmî, Jld. II (Beirut: Dâr alFikr al-Mu'âshir, 1987), hlm.1173. 
tidak sama, maka dalil yang kualitasnya lebih utama yang harus diamalkan. ${ }^{3}$

Ahli hukum Islam tidak searah dalam pengklasifikasian dalil yang bisa ta'ârudl. Menurut mayoritas ulama bahwa antara dua dalil yang qath'î mustahil terjadi bertentangan. Alasan mereka, karena dalâlah (penunjukan) kedua dalil itu menuntut kepastian hukum. Apabila dalil qath'î berlawanan, mestilah terdapat dua hukum yang kontradiktif pada kasus yang sama. Hal itu merupakan suatu kejang galan dan membingungkan, sedangkan hukum Islam berprinsip untuk mempermudah manusia dalam melaksanakan aturan hukumhukumnya. ${ }^{4}$

Sebagian ulama' menganggap mungkin saja terjadi ta'ârudl antar dalil qath'î karena penilaian ke-qath'i-an suatu dalil tergantung pada sudut pandang masing-masing mujtahid. ${ }^{5}$ Perbedaan pendapat ini muncul, tampaknya dilatarbelakangi perbedaan tentang apakah pendapat mujtahid yang berbeda itu benar semuanya atau hanya satu yang benar dan yang lain salah.

Dalam hal ini ulama ushul terbagi dalam dua kelompok; mayoritas ulama mengemukakan bahwa pendapat yang benar hanya satu di antara beberapa pendapat yang berbeda, kelompok ini disebut al-mukhthi'ah. Menurut mereka tidak mungkin terjadi ta'ârudl antar dalil qath'î. Sedangkan minoritas ulama berpendapat tidak menutup kemungkinan semua pendapat mujtahid yang berbeda itu semuanya benar, kelompok ini disebut al-mushawwibah. Menurut mereka bisa saja dua dalil atau beberapa dalil qath'î berlawanan sehingga melahir kan hukum yang berlawanan. ${ }^{6}$

Kalangan ulama ushul juga berseberangan pendapat menge nai kemungkinan berbenturan antara dalil zhannî. Sebagian ulama

3 'Abd al-Wahhâb Khallâf, 'Ilmu ushûl al-Fiqh, (Kairo: Dâr al-'Ilmi, 1978), hlm. 230.

4 al-Ghazâlî, al-Mustashfâ min 'Ilm al-Ushûl, Jld. II (Beirut: Dâr al-Fikr, t.th), hlm. 392, Jamâluddîn al-Asnawî, Nihâyah al-Sawl fî Syarh Minhâj al-Wushûl fî 'Ilm al-Ushûl, Jld. III (Beirut: Dâr al-Kutub al-'Ilmiah, 1983), hlm. 166-167, 'Alî bin Muhammad alÂmidî, al-Ihkâm fî Ushûl al-Ahkâm, Jld. II (Beirut: Dâr al-Fikr, 1996), hlm. 359.

5 Al-Kamâl bin al-Hammâm, al-Taqrîr wa al-Tahbîr, Jld. III, hlm. 3.

6 al-Âmidî, al-Ihkâm fî̀ Ushûl al-Ahkâm, Jld. II, hlm. 323, al-Ghazâlî, al-Mustashfâ min 'Ilm al-Ushûl, Jld. II, hlm. 361, Nizhâmuddîn al-Ansharî, Fawâtih al-Rahamût, Jld. II, hlm. 379, Muhammad al-Khuddarî Bek, Ushûl al-Figh, hlm. 374, Mahmûd bin 'Abdurrahman al-Ashbahanî, Bayân al-Mukhtashar Syarh Mukhtashar Ibn al-Hajîb Fî Ushûl al-Figh, Jld. II (Damaskus: Dâr as-Salam, 2005), hlm. 714. 
mengemukakan pendapat ketidakmungkinan terjadi $t a^{\prime} \hat{a} r u d l$ antara dalil zhannî. Sementara, sebagian ulama lain mengutarakan bahwa mungkin terjadi $t a^{\prime} \hat{a} r u d l$ antara dua dan beberapa dalil zhannî karena dalâlah dalil zhannî sangat relatif sesuai kedalaman analisis dan kejelian masing-masing mujtahid dalam mengungkap kandungan maknanya. Kelompok ini hanya membatasi ketidakmungkinan terjadi ta'ârudl pada dalil qath'î.

Akan tetapi, kedua kelompok tersebut sependapat bahwa ta'ârudl terjadi hanya dalam pemahaman mujtahid, sedangkan subtansinya dalil-dalil itu sendiri tidak mungkin bertolakbelakang. Dalam al-Qur'an tidak mungkin dijumpai perselisihan ayat dengan ayat lain. ${ }^{7}$ Allah berfirman dalam Q.S al-Nisâ’ (4): 82

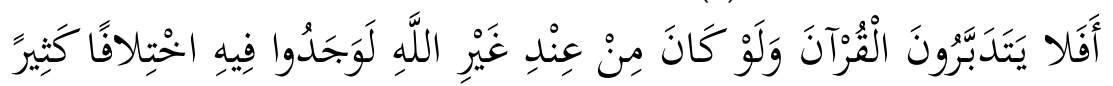

"Maka tidakkah mereka menghayati al-Qur'an, Sekiranya (al-Qur'an) itu bukan dari Allah, pastilah mereka menemukan banyak hal yang bertentangan didalamnya"8

Menurut al-Syâthibî kemungkinan benturan dalil-dalil syara' hanya terbatas pada penampakannya saja. Menurutnya, pertentangan itu bisa terjadi dalam dalil yang qath'î dan bisa juga dalil yang zhann $\hat{\imath}$, selama kedua dalil itu satu derajat. Apabila pertentangan itu terjadi antara dalil yang tidak sederajat maka dalil yang lebih kuat harus diamalkan. Seperti apabila al-Qur'an bertentangan dengan Hadits ahad maka dalil yang dijadikan pedoman adalah al-Qur'an, karena dari segi periwayatannya al-Qur'an bersifat qhath'î sedangkan Hadits ahad bersifat zhannî. ${ }^{9}$ Seirama dengan pandangan ini, Wahbah alZuhaylî berpendapat bahwa pertentangan antara kedua dalil itu

\footnotetext{
7 al-Syâthibî, al-Muwâfaqât fî Ushûl al-Ahkâm, Jld. IV (Beirut: Dâr al-Fikr, t.th), hlm. 294, Muhibbullah bin 'Abd al-Syakûr, Musallam ats-Tsubût, Jld. II (Beirut: Dâr al-Fikr, t.th), hlm. 152.

8 Allah swt memerintahkan kepada hamba-hamba-NYa untuk merenungkan alQur'an, dan melarang untuk melalaikannya. memahami makna-maknanya yang kokoh dan lafadz-lafadz yang indah. Dan Dia juga memberitahukan pada hambahambaNya bahwa di dalam al-Qur'an tidak terdapat pertentangan maupun perselisihan satu ayat dengan ayat lainnya, karena ia diwahyukan dari Dzat Yang Maha Bijaksana dan Maha Terpuji. Lihat, Abu al-Fadâ' Isma'îl bin 'Umar Bin Katsîr, Tafsîr al-Qur'ân al-'Adhîm, Jld. II (Kairo: Dâr al-Fikr, 1999), hlm. 364.

9 Abu Ishâq Ibrahim al-Lakhmî al-Syâthibî, al-Muwâfaqât fî̀ Ushûl al-Ahkâm, Jld. II, hlm. 63.
} 
hanya dalam penilaian mujtahid, bukan pertentangan yang bersifat subtansial, karena sulit diduga apabila syâri' mengundangkan dua dalil yang kontradiktif pada satu kasus dan satu waktu. ${ }^{10}$

\section{Metode-Metode Penyelesaian Dalil-Dalil Ta'ârudl}

Menjadi tugas seorang mujtahid dalam mempertemukan dua dalil yang nampak bertentangan sehingga dapat ditentukan dalil yang kuat untuk dijadikan pijakan hukum. Dalam hal ini, ulama ushul memiliki metode sendiri.

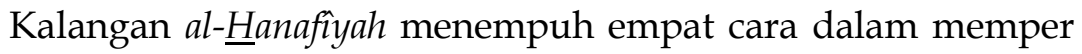
temukan dua atau beberapa dalil yang nampak bertentangan, ${ }^{11}$ yaitu:

1. al-Naskh (menghapus atau membatalkan), yaitu seorang mujtahid harus berusaha meneliti kronologi munculnya kedua dalil itu. Jika telah diketahui mana dalil yang datang pertama dan dalil yang datang kemudian, seorang mujtahid dapat memas tikan dalil kedua menaskh dalil pertama, selama kedua dalil itu sederajat dan dimungkinkan untuk dinaskh.

Misalnya, ayat yang berbicara tentang 'iddah wafat dan 'iddah hamil. Firman Allah swt dalam Q.S al-Baqarah (2) : 234 :

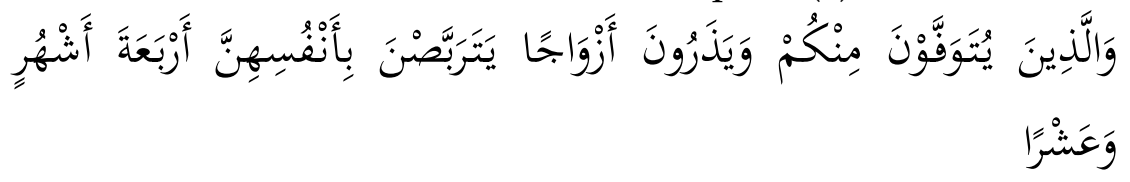

"Dan orang-orang yang mati di antara kamu serta meninggalkan istriistri hendaklah mereka menunggu empat bulan sepuluh hari"

Ayat ini menyatakan bahwa 'iddah wanita yang tinggal mati suaminya adalah empat bulan sepuluh hari. Ayat ini bersifat umum, tidak membedakan apakah wanita itu hamil atau tidak. ${ }^{12}$ Sedangkan dalam Q.S al-Thalaq ayat (65): 4:

10 Wahbah al-Zuhaylî, Ushûl al-Figh al-Islâmî, Jld. II, hlm. 1175

11 Al-Kamâl bin al-Hammâm, al-Taqrîr wa al-Tahbîr, Jld. III, hlm. 3, 'Abdus Syakûr, Musallam al-Tsubût, Jld. II, hlm. 392-395, Nidhâmuddîn al-Ansharî, Fawâtif arRohamût, Jld. II, hlm. 392-395, Muhammad al-Khudarî Bek, Ushûl al-Fiqh, hlm. 358359, 'Abd al-Wahhâb Khallâf, 'Ilmu Ushûl al-Figh, hlm. 229-232.

12 Diriwayatkan dari Ibnu Abbâs bahwa ayat ini menerangkan 'iddah istri yang ditinggal mati suaminya, kecuali jika ia hamil maka masa 'iddahnya sampai melahirkan. Abu Ja'far al-Thabarî, Jâmi' al-Bayân Fî Ta'wîl al-Qur'ân, Jld. V (Beirut: Dar al-Kutub, 2000), hlm. 77, Abu Muhammad al-Husain al-Baghawî, Ma'âlim al-Tanzîl, 


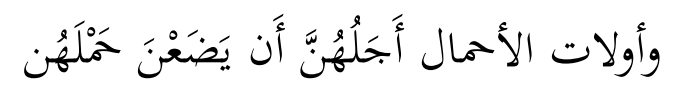

"Perempuan-perempuan yang hamil masa 'iddahnya adalah sampai melahirkan"

Ayat ini menerangkan bahwa 'iddah wanita hamil sampai mela hirkan. Ayat ini pun tidak membedakan apakah wanita hamil ditinggal mati suaminya atau ditalak biasa. Nampaknya, kedua ayat tersebut secara lahiriyah berlawanan. Kekaburan ini dapat dipahami dengan mengetahui latar belakang (asbâb al-nuzĥul) munculnya ayat itu.

Diriwayatkan dari Abdullah bin Mas'ûd bahwa ayat tentang 'iddah wanita hamil diwahyukan setelah ayat 'iddah wafat. De ngan demikian, Q.S al-Thalaq (65): 4 menasakh terhadap Q.S. alBaqarah (2): $234 .{ }^{13}$

2. al-Tarjîh (menguatkan atau mengunggulkan), yaitu meneliti di antara dalil-dalil yang dikumpulkan seorang mujtahid dengan beberapa metode pen-tarjîhan. Metode ini dipakai jika seorang mujtahid tidak mengetahui latarbelakang turunnya/datangnya (asbâb al-nuzûll/asbâb al-wurûd) suatu dalil.

Pentarjîhan dapat diterapkan dengan melihat sisi dalâlah suatu nash, seperti mentarjîh nash yang muhkam (dalâlah lafazhnya jelas dan tidak dapat dinaskh) dari mufassar (dalâlah lafazhnya jelas tapi dapat dinaskh), menguatkan 'ibârah nash dari isyârah nash. ${ }^{14}$ Jika dalil yang saling bertolakbelakang itu adalah antar Hadits, maka pentarjîhan dapat dilakukan dengan memperhatikan kedlâbitan, keadilan, dan integritas si perawi. ${ }^{15}$

3. al-Jam' wa al-Tawfí (menggabungkan dan mengkompromikan). Metode ini ditempuh jika seorang mujtahid tidak dapat meng gunakan tarjîh, karena bertumpu pada prinsip yang dirumuskan

Jld. I (Beirut: Dar al-Kutub al-'Ilmiah, 1997), hlm. 279. Sahabat Abi menyatakan bahwa 'iddah bagi perempuan hamil yang ditinggal mati suami adalah masa yang terlama dari dua 'iddah tersebut. Muhammad al-Baidhawî, Tafsîr al-Baidlawi, Jld. I (Beirut: Dâr al-Fikr, t.th), hlm. 267.

13 Jalâluddîn al-Suyûthî, al-Durrun al-Mantsûr fî̀ al-Ta`wîl bi al-Ma`tsûr, Jld. X (Beirut: Dâr al-Fikr, 1998), hlm. 45.

14 al-Taftâzanî, Syarh al-Talwîh 'alâ al-Taudhîh, (Beirut: Dâr al-Fikr, t.th), 306.

15 Ibid. hlm. 306. 
dalam kaidah "mengamalkan dua dalil yang berbenturan lebih baik daripada meninggalkan keduanya".

Metode ini bisa dalam bentuk menggabungkan dua dalil yang bersifat 'âm, membatasi (taqyîd) atas dua lafazh muthlaq, membagi pada dua lafazh khâsh, dan mentakhsis keumuman lafazh 'am. Contoh dalam masalah darah yang boleh dimakan dan yang haram. Dalam Q.S al-Mâ'idah (5) : 3 Allah SWT berfirman :

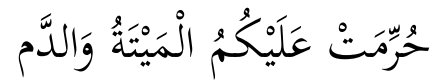

“...diharamkan bagi kalian bangkai dan darah..."16

Pada ayat ini tidak dibedakan antara darah yang mengalir dan darah yang beku. Sedangkan dalam Q.S al-An'âm (6) : 145, Allah berfirman:

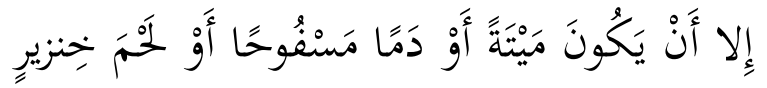

“...kecuali kalau makanan itu bangkai atau darah yang mengalir..."17

Ayat ini menegaskan bahwa darah yang haram adalah darah yang mengalir. Dengan demikian kemutlakan ayat pertama dapat ditaqyîd dengan ayat kedua. Maka, kedua ayat tersebut kandungan hukumnya dapat dikompromikan dan keduanya sama-sama dapat diamalkan.

4. al-Tasaqûth al-Dalîlayn (menggugurkan kedua dalil dan beralih pada dalil lain), apabila ketiga metode sebelumnya tidak mung kin dilakukan, kedua dalil tersebut dapat ditinggalkan. Jika dalil yang bertolakbelakang dan tidak ada jalan dinaskh, ditarjîh atau dikompromikan itu ayal-ayat al-Qur'an, maka seorang mujtahid berpijak pada Hadits dalam ijtihadnya. Dalil lain yang levelnya dibawah kedua dalil yang bertentangan itu, dapat dirujuk.

\footnotetext{
16 Haram hukumnya memakan bangkai, kecuali bangkai ikan dan belalang. Yang dimaksud bangkai adalah setiap binatang yang mati tanpa disembelih sesuai dengan syara'. Begitu pula, haram hukumnya memakan dan meminum darah, yakni darah yang mengalir. Al-Samarqandî, Bahr al-Ulûm, Jld. I (Beirut: Dâr al-Fikr, t.th), hlm. 451, Mahmûd Hâfiduddîn Abu al-Barakat al-Nasahî, Madârik al-Tanzîl wa Haqầ iq al-Ta'wîl, Jld. I (Beirut: Dâr al-Fikr, t.th), hlm. 271.

17 Dahulu masyarakat Jahiliyah menghalalkan sesuatu dan mengharamkan sesuatu. Kemudian Allah SWT. menurunkan ayat ini. Al-Thabarî, Jâmi' al-Bayân Fî Ta'wil alQur'ân, Jld. XII (Beirut: Dâr al-Kutub, 2000), hlm. 190.
} 
Contoh lain kontradiksi antar Hadits, masalah tatacara shalat gerhana. Riwayat Nu'mân bin Basyîr bahwa Nabi. melaksanakan shalat gerhana matahari sebagaimana shalat pada umumnya, yaitu satu rakaat dan dua kali sujud. Hadits kedua dari 'Aisyah bahwa Rasulullah. melaksanakan shalat gerhana matahari dengan dua rakaat, empat rukuk, dan empat sujud.

Kandungan Hadits pertama menunjukkan bahwa tatacara pelak sanaan shalat gerhana matahari adalah satu sujud dan satu i'tidâl sebagaimana shalat lainnya. Sedangkan Hadits kedua mene rangkan shalat gerhana matahari dilakukan dengan dua ruku', dua i'tidâl pada setiap rakaat. Pada dua Hadits tersebut tidak dijumpai faktor untuk ditarjîh. Sebab itulah kalangan Hanafiyah tidak mengamalkan keduanya dan menggunakan qiyâs.

Adapun metode-metode penyelesaian dalil-dalil bertentangan

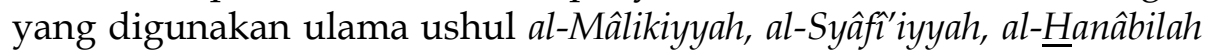
dan al-Zhâhiriyyah adalah sebagai berikut: 18

1. al-Jam' wa al-tawfì bayn al-muta'âridlayn bi wajh maqbûl (mengumpulkan dan mengkompromikan dalil-dalil yang berten tangan sekalipun dari satu sisi). Langkah pertama yang harus ditempuh seorang mujtahid dalam menyelesaikan dalil yang berbenturan, yaitu mengkompromikan dalil-dalil tersebut sekali pun dengan satu aspek saja, ia tidak boleh langsung meng gunakan cara tarjîh.

Prinsip ini dibangun atas kaidah yang berbunyi "mengamalkan kedua dalil lebih baik daripada menyingkirkan salah satunya secara total", sebab hukum asal setiap dalil adalah untuk diamalkan bukan diabaikan. Menurut kalangan ini mengamalkan kedua dalil secara sekaligus bisa berlaku dalam tiga hal: a) membagi hukum pada dua dalil yang bertentangan dengan sebaik-baiknya, b) apabila hukum yang bertentangan itu sesuatu yang dapat dihitung, maka seorang mujtahid boleh mengambil salah satu nya, c) apabila hukum tersebut bersifat umum maka dapat ditakhsîsh.

\footnotetext{
18 Syamsuddîn al-Mahallî, Hâsyiyah al-Bannânî, Jld. II (Beirut: Dâr al-Fikr, t.th), hlm. 359, al-Ghazâlî, al-Mustashfâ min 'Ilm al-Ushûl, Jld. II, hlm. 393, Jamaluddîn al-Asnawî, Nihâyah al-Sawl fî Syarh Minhâj al-Wushûl fi 'Ilm al-Ushûl, Jld. III, hlm. 170-172.
} 
2. al-Tarjîh, seorang mujtahid bila tidak dapat menggunakan meto de pengkompromian, maka dapat men-tarjîh salah satu dalil berdasarkan dalil pendukungnya.

3. al-Naskh. Cara ini ditempuh setelah melewati proses pen-tarjîh-an, yaitu dengan cara membatalkan salah satu hukum yang dikan dung dengan catatan setelah ditelusuri dan diketahui mana yang pertama kali datang dan mana yang kemudian.

4. Al-Tasaqûth al-dalîlayn. Apabila metode-metode di atas tidak dapat dilakukan, maka seorang mujtahid boleh meninggalkan kedua dalil yang bertentangan dan beralih pada dalil yang kualitasnya lebih rendah. ${ }^{19}$

\section{Metode-Metode Tarjîh}

Secara garis besar ulama ushul membagi tarjîh al-adillah pada dua macam, yaitu al-tarjîh bayn al-nushûsh (menguatkan salah satu nash al-Qur'an atau Hadits yang saling bertentangan) dan al-tarjîh bayn al-aqyisah (menguatkan salah satu qiyâs yang saling berten tangan). ${ }^{20}$

Cara-cara mentarjih antara beberapa dalil guna menemukan mana dalil yang lebih kuat, terdapat beberapa cara yang dapat ditempuh, yaitu dengan melakukan penelitian pada: pertama, segi sanad (mata rantai perawi Hadits); kedua, segi matan (teks Hadits); ketiga, segi hukum yang dikandung nash (ayat atau Hadits), dan keempat, pentarjihan dari dalil lain. ${ }^{21}$

\section{a) Tarjîh dari Segi Sanad}

Tarjîh dari segi sanad bisa dilakukan dengan meneliti keotentikan Hadits dari segi perawi, cara periwatannya, apa yang diriwayatkan dan dari siapa Hadits diriwayatkan. Menurut penilaian al-Syaukanî, pentarjihan terhadap sanad dapat ditempuh melalui empat puluh dua cara. ${ }^{22}$

Namun, menurut hemat Wahbah al-Zuhaylî, pentarjihan tersebut dapat dikerucutkan pada empat macam cara:

19 `Abd al-Wahhâb Khallâf, 'Ilmu Ushûl al-Fiqh, 229-231.

20 al-Âmidî, al-Ihkâm fî Ushûl al-Ahkâm, Jld. II, hlm. 359.

${ }^{21}$ Ibid. hlm. 360, al-Taftâzanî, Syarh al-Talwîh 'alâ al-Taudhîh (Beirut: Dar al-Fikr, t.th), hlm. 306.

22 Al-Syawkanî, Irsyâd al-Fuhûl, hlm. 245 
1) Menguatkan salah satu nash dengan memperhatikan pera winya. Hal ini bisa dilakukan dengan cara melihat sisi kuantitas para perawi. Menguatkan Hadits yang sanadnya lebih banyak daripada Hadits yang sanadnya lebih sedikit karena kecil kemungkinan terjadinya kesalahan atas Hadits yang diriwayatkan banyak perawi. Pendapat ini diutarakan jumhûr ulama ushul. ${ }^{23}$ Contoh masalah keharaman riba nasî ah yang ditegaskan oleh al-Syâfi'î dalam al-Risâlah-nya, karena didukung Hadits yang diriwayatkan dari 'Ubadah bin Shâmit, Umar, Utsmân, Abu Sa'id dan Abû hurairah. Sedangkan, Hadits yang satunya diriwayatkan hanya dari seorang Usamah. Namun menurut Abu Hanîfah, Abu Yusuf dan Abu al-ㅍasan Ubaidillah bin Hasan al-Kurkhî menyatakan bahwa pentarjihan tidak cukup berpedoman pada kuantitas perawi semata, kecuali jumlah perawi mencapai tiga orang (Hadits masyhûr).

Kalangan Hanafiyah tidak mensunnahkan mengangkat tangan ketika rukuk. Hal ini, didasarkan pada Hadits Ibnu Mas'ûd bahwa Nabi mengangkat kedua tangan pada saat takbiratul ihram, kemudian tidak mengulanginya lagi. Menurutnya, Hadits ini diriwayatkan empat puluh tiga sahabat.

Mereka menandaskan pendiriannya dengan menganalogikan pada kasus persaksian ketika terjadi pertentangan. Seorang hakim tidak boleh memutuskan perkara jika kedua saksi yang bertentangan mengemukakan persaksian di depan persida ngan karena persaksian yang satu didukung beberapa orang dibanding kesaksian yang lain. ${ }^{24}$

Sementara itu, Wahbah al-Zuhaylî mengkritisi pendapat ini dengan ungkapan bahwa kuantitas perawi dapat menguatkan

23 Al-Âmidî, al-Ihkâm fî Ushûl al-Ahkâm, Jld. II, hlm. 360, Muhammad bin Muhammad al-Ghazâlî, al-Mustashfâ min 'Ilm al-Ushûl, Jld. II, hlm. 395, 'Abd al-Syakûr, Musallam al-Tsubût, Jld. II, hlm. 206-207, Imam Jamaluddîn al-Asnawî, Nihâyah as-Sawl fî Syarh Minhâj al-Wushûl fí 'Ilm al-Ushûl, Jld. III, hlm. 203, Muhammad bin Husain alBazdawî, Kasyf al-Asrâr (Beirut: Dâr al-Fikr, t.th), hlm. 253, Al-Zarkasyî, al-Bahru alMuhith (Beirut: Dar al-Fikr, 1997), 437.

${ }^{24}$ Al-Ansharî, Fawâtif ar-Rohamût, Jld II, hlm. 310, Abd al-Syakûr, Musallam ats-Tsubût, Jld. II, hlm. 310, al-Kamâl bin al-Hammâm, al-Taqrîr wa al-Tahrîr, Jld III, hlm. 33. Muhammad bin Husain al-Bazdawî, Kasyf al-Asrâr (Beirut: Dar al-Fikr, t.th), hlm. 254. 
dalil yang pada mulanya zhannî. Pada sisi inilah pentarjîhan terhadap dalil-dalil diterapkan. ${ }^{25}$ Begitu pula, menurut jumhur ulama pentarjîhan sanad ini dapat ditinjau dari sisi kualitas perawinya. Apabila perawi Hadits lebih dlâbith (kuat inga tannya), lebih wara', lebih taqwa, lebih adil, lebih kredibelitas, lebih faqîh dari perawi Hadits yang lain, maka Hadits yang diriwayatkan darinya lebih berkualitas daripada Hadits lain. ${ }^{26}$ Seperti Hadits yang diriwayatkan 'Aisyah bahwa Nabi pada waktu pagi berada dalam keadaan junub dan tetap berpuasa. Dan ada riwayat lain dari Abu Hurairah bahwa Nabi bersabda: "Basangsiapa pada waktu pagi dalam keadaan junub, maka ia tidak sah puasanya". Dalam kasus ini yang diunggulkan adalah Hadits yang diriwayatkan 'Aisyah, karena ia dinilai lebih mempunyai kapasitas daripada Abu Hurairah. ${ }^{27}$

Dan dapat juga pen-tarjîhan dengan memandang bagaimana cara seseorang menerima dan memelihara Hadits. Hadits yang diterima perawi dan dipelihara dengan hafalannya diung gulkan daripada Hadits yang dipelihara lewat tulisan. Hadits yang rentetan sanadnya masyhûr diunggulkan daripada Hadits yang rentetan sanadnya tidak masyhûr.

2) Perawi yang terlibat langsung dengan apa yang diriwayatkan diunggulkan daripada Hadits yang perawinya tidak terlibat langsung, karena ia lebih tahu peristiwa sebenarnya. Perawi sekaligus pelaku kejadian atas apa yang diriwayatkan lebih berkualitas dibandingkan dengan perawi lain, karena ia lebih mengetahui kejadiannya. Seperti, pernyataan Maimunah bah wa Nabi menikahinya diluar waktu ihram. Tetapi, ada Hadits lain yang diriwayatkan Ibnu Abbas bahwa Nabi menikahi Maimunah sewaktu ia ihram.

\footnotetext{
${ }^{25}$ Al-Zuhaylî, Ushûl al-Fiqh al-Islâmî, Jld. II, hlm. 1179

26 Al-Âmidî, al-Ihkâm fî̀ Ushûl al-Ahkâm, Jld. II, hlm. 360-367, Muhammad bin Muhammad al-Ghazâlî, al-Mustashfâ min 'Ilm al-Ushûl, Jld. II, hlm. 395-397, Abdus Syakûr, Musallam ats-Tsubût, Jld. II, hlm. 206-207, Imam Jamaluddîn al-Asnawî, Nihâyah al-Sawl fî Syarh Minhâj al-Wushûl fì 'Ilm al-Ushûl, Jld. III, hlm. 203, Muhammad al-Khudarî Bek, Ushûl al-Figh, hlm. 367, Syamsuddîn al-Mahallî, Hâsyiyah al-Bannânî, Jld. II, hlm. 363, Al-Zarkasyî, al-Bahr al-Muhîth,hlm. 437.

27 Ibid. hlm. 466.
} 
Dalam hal ini yang dimenangkan adalah Hadits yang diriwa yatkan Maimunah. ${ }^{28}$ Perawi yang lebih dekat dengan Nabi pada waktu menerima Hadits diutamakan dari perawi lain, karena lebih mengetahui duduk perkaranya. ${ }^{29}$ Misalnya, Hadits yang diriwatkan sahabat Ali bahwa Nabi tidak terha lang dari al-Qur'an kecuali ketika junub, itu diunggulkan daripada Hadits riwayat Ibnu Abbas. ${ }^{30}$

3) Pen-tarjîhan dengan meneliti kualitas riwayat itu sendiri. Hadits mutawâtir lebih kuat daripada Hadits masyhûr dan Hadits masyhûr lebih diunggulkan daripada Hadits ahad. Hadits musnad (Hadits yang mata rantai sanadnya bersambung sampai pada Rasulullah) didahulukan dari Hadits mursal (Hadits yang sanadnya terputus). Hadits mursal dari tâbi'în diutamakan dibandingkan Hadits dari tâbi' altâbi'în karena tâbi'în diyakini menerima riwayat dari sahabat yang kejujurannya tidak diragukan lagi. Hadits yang terkum pul pada kitab yang keshahihannya terpelihara (seperti, alBukhâri dan Muslim) lebih diunggulkan daripada Hadits yang terbukukan dalam kitab yang keshahihannya tidak populer. Hadits yang diterima dengan cara qirấah/dibaca langsung oleh guru lebih berkualitas dibandingkan Hadits yang diterima dengan cara membacakan pada guru, atau dengan cara ijâzah, atau dengan lewat tulisan pada lembaran kitab. Hadits yang nilai runtutan sanadnya lebih tinggi (rangkaian sanadnya pendek antara Nabi dengan perawi) didahulukan daripada lainnya, karena semakin pendek jarak isnâdnya, maka semakin tertutup kemungkinan kesalahan dan kebo hongan. ${ }^{31}$

28 Ibid. hlm.470.

${ }^{29}$ Al-Âmidî, al-Ihkâm fî Ushûl al-Ahkâm, Jld. II, hlm. 360-367, al-Ghazâlî, al-Mustashfâ min 'Ilm al-Ushûl, Jld. II, hlm. 395-397, Abd al-Syakûr, Musallam al-Tsubût, Jld. II, hlm. 206-207, Jamaluddîn al-Asnawî, Nihâyah al-Sawl fî Syarh Minhâj al-Wushîl fî 'Ilm alUshûl, Jld. III, hlm. 203, Muhammad al-Khudarî Bek, Ushûl al-Fiqh, 367, Syamsuddîn Muhammad al-Mahallî, Hâsyiyah al-Bannânî, Jld. II, Hlm. 363..

30 Al-Zarkasyî, al-Bahru al-Muhîth, hlm. 472.

31 Al-Âmidî, al-Ihkâm fî̀ Ushûl al-Ahkâm, Jld. II, hlm. 360-367, al-Ghazâlî, al-Mustashfâ min 'Ilm al-Ushûl, Jld. II, hlm. 395-399, Abd al-Syakûr, Musallam ats-Tsubût, Jld. II, hlm. 206-207, Jamaluddîn al-Asnawî, Nihâyah al-Sawl fi Syarh Minhâj al-Wushûl fi 'Ilm alUshûl, Jld. III, hlm. 205, Muhammad al-Khudarî Bek, Ushûl al-Fiqh, hlm. 369. 
4) Pentarjîhan dengan memandang cara menerima Hadits dari Rasulullah. Untuk itu, Hadits yang didengar langsung dari Rasulullah dikuatkan daripada Hadits yang didengar melalui perantara orang lain atau tulisan. Hadits yang diriwayatkan dengan memakai lafazh langsung dari Rasulullah yang menunjukkan kata kerja, seperti kata amara (memerintah), nahâ (melarang), arau adzina (memberi izin) lebih diunggulkan dari lainnya. Hadits yang diriwayatkan dalam bentuk ucapan langsung dari Nabi diutamakan daripada Hadits dalam bentuk riwayat perbuatan dari Nabi.

Begitu juga, diunggulkan Hadits ahad yang kandungan isinya tidak menyangkut orang banyak daripada Hadits ahad yang memuat berita yang menyangkut orang banyak. Sebab, disangsikan kevalidannya jika Hadits yang memuat ketera ngan yang menyangkut banyak orang dengan hanya diriwayatkan segelintir orang. Karenanya, Abu Hanifah mene gaskan apabila kandungan berita Hadits menyangkut orang banyak, riskan sekali disampaikan oleh Rasulullah hanya kepa da satu, dua dan tiga orang. ${ }^{32}$

5) Pentarjîhan berdasarkan pada sumber tempat menerima riwayat. Dengan ketetapan, Hadits yang diriwayatkan dari perawi yang tidak mengingkari periwayatannya dimenangkan daripada Hadits yang perawinya sendiri mengingkari periwa yatannya. Hadits yang diingkari oleh sumber pertama karena unsur kelupaan diunggulkan daripada Hadits yang diingkari atas dasar kebohongan. ${ }^{33}$

\section{b) Tarjîh dari Segi Matan}

Yang dimaksud dengan matan pada segmen ini adalah teks yang dikandung kitab, sunnah dan ijmâ', yang berbentuk amar, nahyi, 'âm, dan khâss. Al-Âmidi menyebutkan terdapat lima puluh satu cara pentarjihan dari segi matan. Diantaranya adalah:

1) Teks yang menunjukkan larangan (nahy) diunggulkan dari pada teks yang mengandung perintah (amar), karena menolak

32 Al-Âmidî, al-Ihkâm fî̀ Ushûl al-Ahkâm, Jld. II, hlm. 362-364. Al-Ghazâlî, al-Mustashfâ min 'Ilm al-Ushûl, Jld. II, hlm. 395-396, Muhammad al-Khudarî Bek, Ushûl al-Fiqh, hlm. 367.

33 Al-Âmidî, al-Ihkâm Fî Ushûl al-Ahkâm, Jld. III, hlm. 365. 
pelbagai kemafsadatan lebih didahulukan daripada mengam bil manfaat,

2) Teks yang mengandung perintah dimenangkan atas teks yang menunjukkan kebolehan, karena melaksanakan perintah seca ra ekplisit melaksanakan anjuran kebolehan,

3) Makna hakikat dari suatu lafazh dikedepankan daripada makna majaz, karena makna hakikat yang segera ditangkap akal dan tidak memerlukan indikasi lain untuk memahaminya

4) Dalil khâsh lebih didahulukan daripada dalil 'âm, karena dalâlah khâsh lebih kuat dan lebih tertentu pada hukum yang dikandung,

5) Teks umum ('âm) yang belum ditakhshîsh lebih didahulukan dari teks umum yang sudah ditakhshîsh, karena teks yang sudah ditakhshîsh menjadi majaz,

6) Lafazh muhkam lebih diunggulkan daripada lafazh mufassar, lafazh mufassar lebih dimenangkan daripada lafazh nash, dan lafazh nash lebih diutamakan daripada lafazh zhâhir, lafazh yang sharîh lebih dikedepankan daripada kinâyah, lafazh majaz lebih diamalkan daripada musytarak, ibârah lebih didahulukan daripada isyârah; isyârah lebih diutamakan daripada dalâlah dan dalâlah lebih diunggulkan daripada iqtidhấ.

7) Kalimat jama' yang ma'rifat lebih diunggulkan daripada kalimat jama' yang nakirah, dan

8) Qaul (perkataan) lebih dimenangkan daripada fi'il (perbuatan), karena keterangan melalui perkataan lebih jelas daripada perbuatan. ${ }^{34}$

\section{c) Tarjîh dari Segi Hukum atau Kandungan Nash}

Menurut al-Âmidî terdapat sebelas cara pentarjîhan dari segi hukum, sedangkan al-Syawkanî mengerucutkan menjadi bebe rapa cara berikut:

1) Mengenai apabila salah satu nash menunjukkan larangan sedangkan nash yang lain mengarah pada kebolehan, terdapat persilangan pendapat diantara ulama, menurut jumhûr ulama,

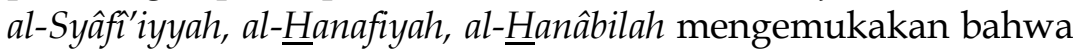
nash yang menunjukkan larangan itu lebih diunggulkan.

34 Ibid. hlm. 365-372, ’Abd al-Syakûr, Musallam al-Tsubût, Jld. II, hlm. 208-209. 
Sedangkan Abu Hasyim, Isa bin Abân dan al-Ghazâlî menya takan kedua dalil itu sama-sama tidak diamalkan kare na tidak ada yang dapat didahulukan.

Al-Ghazâlî merasionalkan pendapatnya dengan alasan bahwa nash yang menunjukkan kebolehan didukung kaidah asal pada segala sesuatu, yaitu boleh. Sedangkan nash yang me muat keharaman diperkuat dengan dalil ihtiyâth (kehatihatian). Karena itu, kualitas keduanya adalah sama. Dalam kondisi seperti itu sulit untuk mentarjih diantara kedua. Maka jalan yang paling mungkin menggugurkan keduanya,

2) Namun sebagian ulama mengatakan nash yang mengandung kebolehan diunggulkan daripada nash yang menyeru kehara man. Argumen yang diutarakan jumhûr ulama ada lah Hadits Nabi: "Tidak pernah berkumpul yang halal dan yang haram, kecuali yang lebih dominan adalah yang haram" (HR. al-Baihaqi). Alasan kedua adalah sikap ihtiyâth (kehati-hatian) agar tidak terje rumus pada yang haram,

3) Apabila hukum yang dikehendaki suatu nash menunjukkan ketetapan (itsbât), sedangkan nash yang lain menunjukkan pada peniadaan (nafy). Dalam persoalan ini terdapat aneka ragam pendapat diantara ulama. Menurut jumhûr ulama nash yang mengandung sifat menetapkan didahulukan daripada nash yang menunjukkan sifat meniadakan. Argumen yang mereka kemukakan karena nash yang bersifat tambahan mem beri informasi tambahan. Misalnya, Ibnu Abbas meriwa yatkan sebuah Hadits bahwa Rasulullah kawin dengan Maimu nah dalam keadaan ihram (HR. al-Bukharî dan Muslim).

Sebaliknya, di riwayat lain dijumpai keterangan bahwa Rasulullah mengawini Maimunah bukan dalam keadaan ihram (HR. Imam Malik). Dalam kasus seperti ini jumhûr ulama mendahulukan Hadits yang sifatnya menetapkan. Sedangkan, menurut al-Syâfítiyyah nash yang sifatnya menia dakan (nafy) diunggulkan daripada nash yang sifatnya mene tapkan (itsbat). Karena itu, Hadits yang diriwayatkan imam Mâlik lebih layak diamalkan daripada Hadits yang diriwa yatkan al-Bukhâri dan Muslim,

4) Sementara itu, Isa bin Abân, al-Ghazalî dan Qâdî 'Abd alJabbâr lepas haluan dengan kedua pendapat di atas, menurut 
mereka kedua hukum itu digugurkan, karena keduanya mungkin be nar dan tidak menutup kemungkinan juga salah. Oleh karena itu, pen-tarjîhan pada kasus ini membutuhkan indikasi lain,

5) Nash yang mengandung hukum menghindarkan terpidana dari hukuman lebih dimenangkan daripada nash yang mewa jibkan hukuman pada terpidana, karena syari'at Islam menge depankan menolak keburukan daripada mengambil manfaat,

6) Nash yang mengandung hukum wadl'î diunggulkan daripada nash yang memuat hukum taklîfi. Tetapi, menurut Hanafiyah dan mayoritas al-Syâfi'iyyah nash yang berisi petunjuk hukum taklîfi dimenangkan daripada nash yang memuat petunjuk hukum wadl'î,

7) Nash yang memuat materi hukuman lebih ringan diung gulkan daripada nash yang memuat materi hukuman berat, karena hukum Islam dibangun atas semangat keringanan. ${ }^{35}$ Sebagaimana firman Allah dalam Q.S al-Baqarah (2) ayat 185 yang artinya "...Allah menghendaki kemudahan bagimu, dan tidak menghendaki kesukaran bagimu".

\section{d) Tarjîh dengan Menimbang Faktor di Luar Nash}

Al-Âmidî menyebutkan terdapat lima belas macam pentarjîhan dengan mempertimbangkan faktor di luar nash. Di antaranya adalah:

1) Dalil yang diperkuat dalil lain, baik al-Qur'an, as-sunnah, ijmâ', qiyas, logika dan indera lebih diutamakan dari dalil lain,

2) Mendahulukan dalil yang sesuai dengan amaliah penduduk Madinah, atau yang dipraktekkan al-Khulafấ al-Râsyidîn dan mayoritas umat karena penduduk Madinah banyak menge tahui persoalan turunnya al-Qur'an, dan banyak mengetahui penafsiran dan takwîl serta adanya anjuran Rasulullah untuk meneladani mereka,

3) Menguatkan nash yang menyebutkan 'illat hukumnya dari pada nash yang tidak menegaskan 'illat hukumnya. Begitu pula, lebih kuat hukum yang diketahui latar belakang

35 Al-Âmidî, al-Ihkâm fî Ushûl al-Ahkâm, Jld. II, hlm. 372-376. 
turunnya (asbâb al-nuzĥul/asbâb al-wurûd) daripada nash hukum yang tidak diketahui latar belakang turunnya,

4) Mengutamakan dalil yang mengandung sifat ihtiyâth dan albarô'ah al-zhimmah (bebas dari tanggungan) daripada nash lain,

5) Mendaluhukan dalil yang disertai penjelasan dari perawinya dan dalil yang sesuai dengan perbuatan dan perkataan perawi karena dialah yang amat mengetahui tentang apa yang diriwa yatkannya,

6) Mendaluhukan dalil yang diamini oleh sahabat yang menda pat keistimewaan dari Nabi, seperti Zaid dalam bidang farâidl, Muadz dalam bidang fiqh dan Ali dalam bidang peradilan,

7) Menguatkan dalil yang kemungkinan dapat dinasakh dari pada lainnya,

8) Mendahulukan dalil yang tidak mengisyaratkan kehinaan sahabat dari yang lain, dan

9) Menguatkan dalil yang perawi menyebutkan sebab-sebab datangnya (asbâb al-wurûd) khabar dari yang lain. ${ }^{36}$

\section{Penutup}

Dari pemaparan tulisan ini, dapat dipetik beberapa kesim pulan, yaitu: pertama, apabila terdapat dua atau beberapa dalil yang berta'ârudl, maka seorang mujtahid dituntut untuk mencurahkan segenap nalar ijtihadnya guna menemukan dalil yang râjih. Kedua, ulama ushul dari kalangan al-Hanafiyyah, al-Mâlikiyyah, al-Syâfi'iyyah, al-

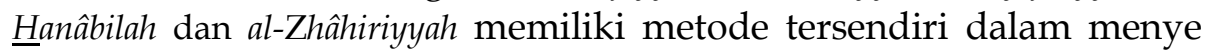
lesaikan masalah $t a^{\prime} \hat{a} r u d l$ antar dalil, sebagaimana telah diuraikan.

Karenanya, pencetus hukum Islam masa kini setelah mengana lisis metode-metode yang mereka bangun dengan pelbagai pertim bangan nalar akal, naql dan mashlahah. Dan ketiga, ulama ushul juga merumuskan metode tarjîh guna menguatkan dan mengunggulkan antara dalil-dalil yang bertentangan.

Metode tarjîh ini dapat dilakukan dengan memperhatikan secara cermat pada beberapa segi, yaitu a. segi sanad (mata rantai perawi Hadits), b. segi matan (teks Hadits), c. segi hukum yang dikan dung nash (ayat atau Hadits) dan d. Pen-tarjîhan dari dalil lain. Hal

\footnotetext{
36 Al-Âmidî, al-Ihkâm fî Ushûl al-Ahkâm, Jld. II, hlm. 376-379, Abdus Syakûr, Musallam
} al-Tsubût, Jld. II, hlm. 208-209. 
ini, penting dilakukan dalam rangka memilah dan memilih dalil yang benar-banar râjih diantara beberapa dalil yang berkaitan, sehingga produk hukum yang digulirkan sesuai dengan ketetapan al-Qur'an dan tuntunan Hadits shahîh.

\section{Daftar Pustaka:}

Âmidî, 'Alî bin Muhammad al-. al-Ihkâm fî Ushûl al-Ahkâm. Bairut: Dâr al-Fikr, 1996.

Ansharî, Muhammad bin Nidhâmuddîn al-. Fawâtif al-Rahamût. Bairut: Dâr al-Fikr, t.th.

Ashbahânî, Mahmûd bin 'Abdurrahman al-. Bayân al-Mukhtashar Syarh Mukhtashar Ibn al-Hajîb Fî Ushûl al-Figh. Damaskus: Dâr al-Salam, 2005.

Asnawî, Imam Jamaluddîn al-. Nihâyah al-Sawl fî̀ Syarh Minhâj alWushîl fî̀ 'Ilm al-Ushûl. Bairut: Dâr al-Kutub al-'Ilmiah, 1983.

Baidlâwî, Muhammad al-. Tafsîr al-Baidhawi. Bairut: Dâr al-Fikr, t.th.

Baghawî, Abu Muhammad al-Husain al-. Ma'âlim al-Tanzîl. Bairut: Dar al-Kutub al-'Ilmiah, 1997.

Bazdawî, Muhammad bin Husain al-. Kasyf al-Asrâr. Bairut: Dâr alFikr, t.th.

Ghazâlî, Muhammad bin Muhammad al-. al-Mustashfâ min 'Ilm alUshîl. Beirut: Dâr al-Fikr, t.th.

Hammân, Imam al-Kamâl bin al-. al-Taqrîr wa al-Tahbîr fî̀ 'Ilm al-Ushûl al-Jâmi' baina Isthilâhai al-Hanafiyah wa al-Syâfi'iyyah. Bairut: Dâr al-Kutub al-'Ilmiah, 1983.

Katsîr, Abû al-Fadâ' Isma'îl bin 'Umar Bin. Tafsîr al-Qur'an al-'Azhîm. Kairo: Dâr al-Fikr, 1999.

Khallâf, Abdul Wahhâb. 'Ilm Ushûl al-Fiqh. Kairo: Dâr al-'Ilmu, 1978.

Khudharî, Bek Muhammad al-. Ushûl al-Fiqh. Bairut: Dâr al-Fikr, 1988.

Mahallî, Syamsuddîn Muhammad al-. Hâsyiyah al-Bannânî. Bairut: Dâr al-Fikr, t.th.

Nasafî, Mahmûd Hâfiduddîn Abu al-Barakât al-. Madârik al-Tanzîl wa Haqâ 'iq al-Ta'wîll. Bairut: Dâr al-Fikr, t.th.

Samarqandî, al-. Bahr al-Ulûm. Bairut: Dâr al-Fikr, t.th.

Suyûthî, Jalâluddîn al-. al-Durrun al-Mantsûr fî̀ al-Ta’wîl bi al-Màtsûr. Bairut: Dâr al-Fikr, 1998. 
Syakûr, Muhibbullah bin 'Abd al-. Musallam al-Tsubût. Bairut: Dâr alFikr, t.th.

Syâthibî, Abu Ishâq Ibrahîm al-Lakhmî al-. al-Muwâfaqat fî̀ Ushûl alAhkâm. Bairut: Dâr al-Fikr, t.th.

Syawkanî, Muhammad al-. Irsyâd al-Fuhûl. Bairut: Dâr al-Fikr, 1998. Taftâzanî, al-. Syarh al-Talwîh 'alâ al-Taudhîh. Bairut: Dâr al-Fikr, t.th.

Thabarî, Abu Ja'far al-. Jâmi' al-Bayân fî Ta'wîl al-Qur'an. Bairut: Dar alKutub, 2000.

Zarkasyî, Abdullah al-. al-Bahr al-Muhîth. Bairut: Dar al-Fikr, 1997.

Zuhaylî, Wahbah al-. Ushûl al-Fiqh al-Islâmî. Bairut: Dâr al-Fikr alMu'âshir, 1987. 